\title{
IMPACT OF PUBLIC DEBT ON ECONOMIC GROWTH: AN EMPIRICAL INVESTIGATION FROM SOUTH ASIAN COUNTRIES
}

\author{
Muhammad Reehan Hameed $^{1 *}$, Ghulam Sarwar ${ }^{2}$, Shahid Adil ${ }^{3}$, Hafsah Batool ${ }^{4}$, Israr Hussain ${ }^{5}$ \\ ${ }^{1 *}$ Assistant Professor, Department of Economics, Government College of Science, Wahdat Road, Lahore, Pakistan; \\ ${ }^{2}$ Assistant Professor, Noon Business School, Faculty of Social Sciences, University of Sargodha, Pakistan; ${ }^{3}$ Director, \\ Punjab Economic Research Institute, Punjab, Pakistan; ${ }^{4}$ Lecturer, Department of Economics, Lahore College for Women \\ University (LCWU), Punjab, Pakistan; ${ }^{5}$ Ph.D. Scholar, Superior University, Lahore, Punjab, Pakistan. \\ Email: "reehanhameed@yahoo.com
}

Article History: Received on $9^{\text {th }}$ February 2021, Revised on $20^{\text {th }}$ March 2021, Published on $24^{\text {th }}$ March 2021

\begin{abstract}
Purpose of the study: This study aims to analyze the short-run and as well as long-run effects of public debt on the economy of South Asian countries. And to resolve problems in managing and servicing their massive public debt obligations.
\end{abstract}

Methodology: For econometrically investigation, panel data has been used for the era of 1990-2019. For obtaining econometric outcomes, we applied the Fixed Effect Model and PMG/ Panel ARDL.

Main Findings: The results revealed that public debt negatively affected the economic performance of these countries. This effect is adverse both in short as well as in long period.

Applications of this study: The study can be effective for simultaneous achievement of the desirable level of economic growth and public debt stock seems to be difficult and could remain elusive if some serious measures have not been taken.

Novelty/Originality of this study: The study recommends the efficient and productive utilization of borrowed funds to avoid their negative repercussions.

Keywords: Public Debt, Economic Growth, South Asia, Fixed Effect Model, Panel ARDL/PMG.

\section{INTRODUCTION}

The persistent rise in public debt of developing countries is a sign of economic slowdown and inappropriate debt management. Improper structural reforms, defective macroeconomic policies, a weak export base, unproductive utilization of borrowed funds, and an unfavorable political environment are considered to be the root cause of this high public debt burden (Zaidi, 2015). The growing public debt results in decreasing both local and foreign investment, which further slows down the pace of capital accumulation and productivity. Moreover, huge public debt stock results in crowding out of physical capital and distress human capital accumulation (Serieux \& Samy, 2001). Economic theories believe that proper borrowings stimulate economic performance by growing the contents of investment and output growth. Counties in the initial stages of growth usually have a smaller amount of capital stock and limited investment opportunities. On the other hand, in developing economies, the burden of accumulating debt results in disrupting macrocosmic stability and local and foreign investment. Although generating resources through internal and external sources is very much important for instigating the pace of economic growth. Nevertheless, a continuous rise in public debt burden over a longer period put serious threats to economic performance. The effect of public debt on growth depends upon its nature and utilization. Public debt helps the economy if it is utilized for productive purposes. While unproductive debt is not self-liquidating and having no impact on productivity growth. Consequently, the investment made through public borrowings must generate so many returns that could be used to repay the principal amount and its services charges (Adebusola et al. 2007). South Asian countries, like other developing economies, pray for a shortage of resources to meet their development needs. To fill the gap between revenue and expenditures, they are persistently relying on both domestic and foreign debt. This phenomenon of twin deficits results in increasing the public debt burden in these countries. The huge debt burden and increasing debt servicing are considered to the major contributor in slowing down economic growth. Many countries lose their comparative advantage in the international market due to inadequate exchange rate adjustments. Further, deteriorating terms of trade, financial mismanagement, and bad governance also depend on the growth rate in these countries. The situation was more acute in those countries having a high burden of debt because these counties faced higher debt servicing charges of debt, a decrease in the inflow of foreign resources, low export potential, low level of domestic output, and lesser imports. In Pakistan, domestic debt increases to $8 \%$ in the early 1980s, and it rises to $22 \%$ until the end of the 1980s (Anwar, 1995). The domestic and foreign debt situation was further aggravated in the 1990s. The external debt to GDP ratio in 1998-99 increase to 43 percent while it was 34 percent in 1990-91. On the other hand, domestic debt in Pakistan during the 1990s had observed to grow 13.7 percent annually. Despite the increasing invasion of far-off capital in the form of foreign aid, South Asia has come out of the world's underprivileged and uneducated expanses. Where more than 500 million people are bound to live in poverty, and the world's 46 percent illiterate live in South Asia (UNDP, 1997). This region comprises almost 22 percent of the world's total population, and its share in the world's total income is just 1.3 percent. According to (Zaidi, 2015), South Asia emerged as one of the highly indebted regions of the world. Thus, South Asia counties come into the $21^{\text {st }}$ century with 
these challenges as mentioned above. Despite the large inflow of foreign resources, economic environments persisted worsens in the region. Such a status quo demands a comprehensive package of foreign assistance. Public debt to GDP ratio in South Asian economies showing an increasing trend from the last three decades. As in 1990, it was 0.50 in Bangladesh, 0.51 in Bhutan, 0.71 in India, 0.31 in Nepal, 0.53 in the Maldives, 0.82 in Pakistan, and 0.29 in Sri Lanka. In 2019 public debt to GDP ratio is 1.11, the highest Bhutan among South Asian countries as compares to 0.35 in Bangladesh, 0.69 in India, 0.65 in Nepal, 0.25 in the Maldives, 0.77 in Pakistan, and 0.87 in Sri Lanka (Molina et al., 2020). Increasing Public debt has threatened the future of South Asian countries and demand special attention to minimize it. Public debt has now become one of the essential issues of all the developing countries of the world. The country poorest in the world is also the most highly indebted. There is no doubt in the minds of economists, sociologists, political scientists, or the common public that debt has become a burden to the poor nations. Therefore, public debt is the most significant phenomenon in the present world. Pakistan, India, and Bangladesh are some of the major borrowers among South Asian Countries. Their population is 1/5 of the total world population (1.2 billion). However, they spend only $5 \%$ of the combined GNP on their people. The massive problem of public debt is considered to be a common issue and needs to be addressed together by South Asian countries. In this connection, in January 2008 the first workshop of the South Asian region was held in Colombo. It was commonly decided that all South Asian countries raise their voices against the policies of the International Financial Institutions regarding debt on one platform (Saez, 2012). The above discussion reveals that keeping in view the common challenges in South Asian countries, a comprehensive "Freedom from Debt Domination" campaign at the regional and international level against debt is the need of the hour. A historical look at public debt is presented here in table 1.

Table 1: Public Debt to GDP Ratio of South Asian Countries

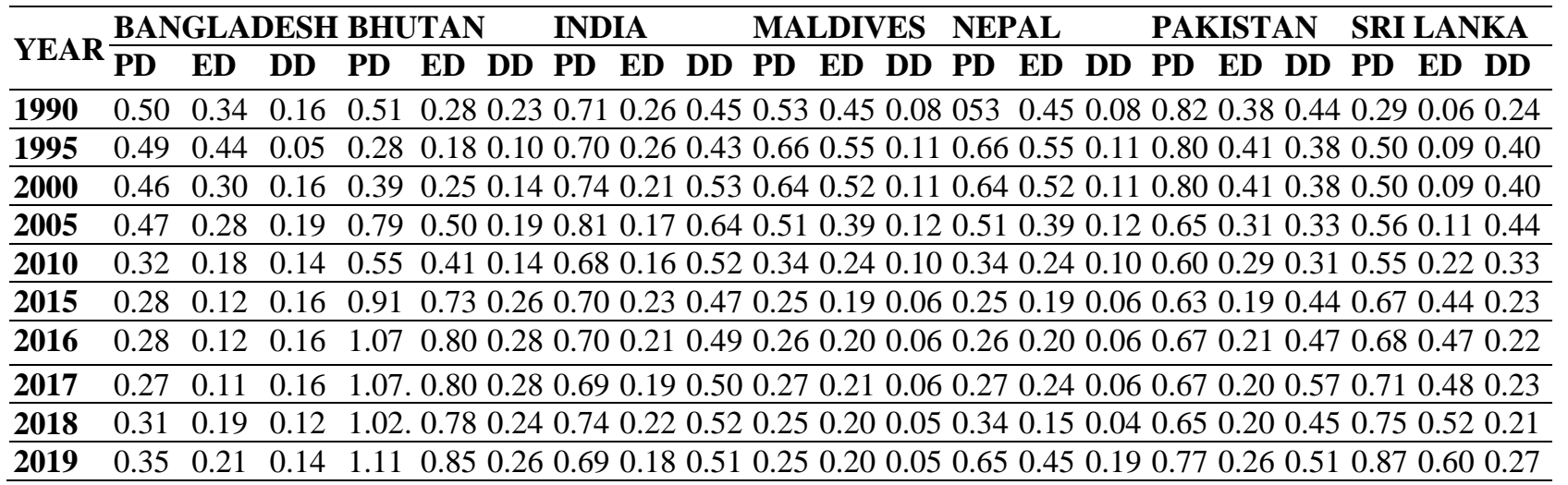

Source: International Debt Statistics various databases.

$* \mathrm{PD}=$ Public Debt, $*$ ED $=$ External Debt,$* \mathrm{DD}=$ Domestic Debt

Public debt has a major economic impact, both in the short and long term. The prevailing belief is that debt can enhance accumulated demand and output in the immediate future, but it long lines out capital and reduces output in the long run. Thus, the whole study refers to the long impact of South Asian Countries' debt.

\section{LITERATURE REVIEW}

Jointly empirical and theoretical literature is accessible on the interconnection concerning the public debt and growth. It endorses the venomous concerns of public borrowing for economic growth and other socio-economic indicators. Conferring to Agenor and Montiel (1996) argued that a huge volume of debt affects growth over and done with depressing total factor productivity. By the same token, Krugman (1988), once debt compulsions in an economy exceed in the form of borrowings, it depresses growth and investment performance. It also infers that at higher levels of debt encumbrances, stakeholders would suppose low returns on their nest egg. The outcomes of Gong \& Zou (2000) divulge that overseas borrowings destructively affect investment accretion in the long-run. Lin and Sosin (2001) analyzed the linkage between overseas funding and the economic growth of seventy-seven countries. They disjointed the whole sample consistent with a regional classification such as Asia, Africa, Latin America, and Industrialized countries. In the African nation, they found a statistically significant and an inverse association between overseas funding and economic growth. In industrialized nations and Latin American economics, the relationship was inversed but not significant. Likewise, they found a positive and statistically insignificant linkage in the case of Asian countries. Ward et al. (2002) examined the relationship between foreign indebtedness on economic growth. For this purpose, 29 years of data of 93 developing countries starting from 1969-1998 had been used. The Fixed Effect Model and Generalized Methods of Movement (GMM) had been used for the analysis of data. The results indicated that along with doubling the debt level, the growth rate would reduce between 50 to 100 percent. Maghyereh (2003) surveyed the effect of overseas indebtedness on the growth performance of Jordan. For this purpose, 31 years of data from 1970 to 2000 had been used. The fallouts showed that up to 53\% of GDP debt had affected growth positively. But beyond that level, the effect became negative. Mohamed (2005) examined the debt and growth relationship in Sudan. For this purpose, the 23 years 
of data from 1978-2001 had been used. The results exhibited that foreign debt and economic growth were negatively related to each other. Gurbuz et al. (2007) studied the issue of debt sustainability and management in Turkey. They used quarterly data from 1998 to 2002. The econometric outcomes had revealed that the public debt of Turkey was not sustainable. They found a few causes of non-sustainability. Among them, a huge level of inflation, uneven economic growth, pitiable managing of public debt, and political unpredictability were prominent. Bakar and Hassan (2008) explored how debt affected growth. For this purpose of 36 years, data of the Malaysian economy from 1970 to 2005 had been used. For the analysis of the data, the VAR approach had been used. The outcomes revealed that foreign debt and economic growth had been negatively associated with each other in Malaysia. Butts (2009) explored the linkage between foreign indebtedness and growth. For this purpose, 27 Latin American and Caribbean economies were included in the study. For analysis, 33 years of data from 1970 to 2003 had been used. The results showed that bidirectional causality prevailed between foreign indebtedness and growth. This long-run association indicated that the short-term dynamics were particularly interrelated to policies that followed their outcomes and some macroeconomic shocks which were affected by the size of foreign debt. Reinhart and Rogoff (2010) found out the association between growing public indebtedness, growth performance, and inflation. They used the data of 44 developed countries. The results indicated that after a specific level of debt to GDP ratio (90\% and above), public indebtedness had affected growth negatively in developed countries. Amassoma (2011) studied the influence of external borrowings and internal borrowings on the growth performance of Nigeria. They used the data of 39 years between 1970 and 2009. They had used VAR and VEC techniques for analysis. The outcomes exposed a bi-directional causality between internal borrowings and growth. Berben \& Brosens (2007) presented an endogenous growth model with the inclusion of public debt and spending. He analyzed poles apart debt strategies vis-à-vis conjunction to a stable growth pathway. He also estimated their impacts on economic growth and well-being. He found a balanced budget rule for sustainable growth. In this rule, public debt raises but below entirely other economic indicators and causes similar stable growth. Tchereni et al. (2013) analyzed the relationship between foreign debt on the economic growth of Malawi. Time-series Data from1975-2003 with annual frequencies. The econometric investigation indicated a destructive connection between foreign indebtedness and economic growth in Malawi. Mbate (2013) estimated the effects of internal debt on growth in twenty-one sub-Saharan African economies. They built a dynamic cross-country model and applied System-GMM for econometric exploration. The results revealed a non-linear rapport concerning internal debt and economic growth. Furthermore, internal debt was originated to crowd out private sector credit, preventing capital accretion and private investment. Fincke and Greiner (2015) empirically studied the liaison between public debt and economic growth for a selection of emerging market economies. The domino effect revealed a positive association between debt and growth. Population and physical capital also had a positive link with growth. While the initial level of GDP exerted a deleterious effect on growth (Ravallion, 1997). It implied conditional convergence. Lopes et al. (2016) analyzed the liaison among public debt, economic growth, and inflation in a collection of 52 African countries. The outcomes designated that public debt was adversely connected to economic growth. Chiu and Lee (2017) explored the linkage between debt and growth using a panel of sixty-one economies. They examined the role of economic, financial, and political risk in the debt-growth nexus. High magnitude of financial and political risk discourses growth with the rise of debt. Public debt upturns economic growth with feeble financial and political risk. Lopez and Nahon (2017) studied the case of Argentina in the debt-growth relationship. They found that in Argentina, it was essential the situation of defensible debt achieves sufficient growth. Intartaglia et al. (2018) studied the impact of public debt on economic growth on both less developed and developed economies. Public debt seems to harm growth in both advanced and backward countries, but not at the same magnitude. While private debt had a dissimilar impact on growth in each type of country. They found that private debt had an inverse association with growth in only developed nations. Swamy (2020) conducted a worldwide study of debt-growth nexus. The study built a dynamic growth model. Time-series data from 1960 to 2009. The results indicated a negative relationship between debt and growth. The results also indicated that the influence of debt on growth was not identical for all economies. Their consequences were different due to debt regimes. It was also due to significant global economic indicators such as price instability, trade indicators, government spending, and inflow of overseas investment. Recently, Hameed and Quddus (2020) analyzed the impact of high and growing debt on economic growth in SAARC. They used panel data from 1990 to 2018 with annual frequencies and PMG and fixed effects for econometric investigation. They originated a negative association concerning public debt and economic growth in the long run and short run in these economies. Ghourchian and Yilmazkuday (2020) examined the influence of government spending and government debt on economic growth in a sample of eighty-three economies. The study revealed that both government outlay and public debt had an undesirable influence on growth performance.

The null hypothesis of this study is that public debt has no impact on economic growth and the alternative hypothesis is that public debt has a significant impact.

\section{METHODOLOGY}

The study has employed the following method.

1. Fixed Effect Model.

2. Panel Unit Root Test.

3. Panel ARDL/PMG. 


\section{Fixed Effect Model}

It is unusual, and when $W_{i}$ is not regulated and has a connection with $\mathrm{K}_{\mathrm{it}}$, we face a complicated situation. In such a case, OLS estimates will be biased and not consistent because the model has an omitted variable. However, under this condition, the model.

$$
Y_{i t}=K_{i t} \beta+\alpha_{i}+\varepsilon_{i t}
$$

Where $\alpha_{i}=W_{i} \alpha$, has all those effects that can be observed, and it enumerates an estimable conditional mean. The Fixed Effect Model considers $\alpha_{i}$ to be a country-specific intercept in the regression model.

\section{Panel Unit Root Test}

The general form of the Panel Unit Root test can be written as

$$
\begin{aligned}
& \qquad y_{i t}=\rho_{i} y_{i t-1}+z^{\prime}{ }_{i t} \gamma+\mu_{i t} \\
& \text { Where } i=1,2, \ldots \ldots, N \text { is the individual, for each individua }=1,2, \ldots, T \\
& \text { time series observations are available, } z_{i t} \text { shows deterministic component and }
\end{aligned}
$$

$$
\mu_{i t} \text { indicates the stationary process. }
$$

\section{Panel Autoregressive Distributive Lag (Ardl)/Pmg Approach}

The study has used a panel ARDL econometric technique for the estimation of the long-run relationship among the variables. The Panel ARDL model is also called the Pooled Mean Group (PMG). The ARDL methodology prevents Endogeneity because it can distinguish between dependent and explanatory variables and can simultaneously estimate the long-term and short-term components of the model. ARDL approach to Cointegration has several advantages and having superiority over other econometric techniques used to find out long-run relationships. The methods require the dependent variable to be integrated at I (1), and neither of the independent variables is at I(2).

\section{Data Source}

For the sake of analysis, panel data of South Asian economies have been used from 1990-2019. Data has been collected from WDI, International Debt Statistics (IDS), and IMF.

\section{Data Analysis Method}

In the social sciences and econometrics, panel data analysis often serves as a basis for two-dimensional panel data evaluation. The data will usually be collected over time and over the same people, and then the two dimensions are reversed. Multidimensional analysis is an econometric method in which more than two-dimensional data are collected.

\section{MODEL SPECIFICATION}

The model used in the study relates economic growth to the public debt burden. Real GDP per capita, which is measured as the natural log of current minus previous year real GDP per capita, is used as a proxy for economic growth. It is used as a proxy to measure economic growth by many previous studies such as Barro (1991), Pervaiz \& Chaudhary (2015), and Ghatak \& Halicioglu (2007). The initial level of income measured as twenty years lagged value of the log of real GDP per capita included in the model as an explanatory variable to check the convergence among countries. The initial GDP is used as a proxy to check the convergence among countries by Pervaiz \& Chaudhary (2015), Barro (1991), and Caselli et al. (1996). Gross fixed capital formation as a share of GDP is used as a proxy to measure capital accumulation in growth regression. The investment enhances the level of production and generates employment opportunities. This, in turn, positively stimulates economic growth. This proxy was used by many previous studies by Munnell (1992), Pervaiz and Chaudhary (2015), and De Long \& Summers (1991). The growth model is inappropriate without including the role of human capital in the model, as argued by Romer (1990) and Benhabib \& Spiegel (1994). The secondary school enrollment rate (SSER) is used as a proxy for human capital. Secondary school enrollment rate (SSER) is used as a proxy for human capital by Barro (1991) and Mankiw et al. (1992). Education enhances the future productivity of the labour force and future income. Foreign direct investment (FDI) as a share of GDP is an essential factor for economic growth in the developing countries as argued by Azman-Saini, (2010) is used as an independent variable in the model. FDI as a share of GDP in the growth model is also used by Pervaiz \& Chaudhary (2015), Sunde (2017), and Herzer (2008). Trade openness measures as export plus import divided by GDP included examining the impact of trade liberalization on economic growth. Trade liberalization can stimulate economic growth positively by enhancing the availability of public goods and services, bringing efficiency in resource allocation, and increase total factor productivity (TFP) through technology transfer and knowledge sharing (Barro and Sala-i-Martin, 1997). Trade openness was used as a proxy to see the impact of trade liberalization on economic growth (Huang \& Chang, 2014). Financial development measures as domestic credit as a share of GDP are used as an explanatory variable in the model. It is a better measure of financial development, as argued by Harmon (2012). It increases the returns from the capital by enhancing the efficiency of investment. It minimizes the cost of borrowings, which stimulates investment (Shonchoy, 2010). It also increases the savings in the economy, which accelerates the pace of economic growth in the country. Domestic credit, as a share of 
GDP, is used as a proxy for financial development (Levine, 2005). The public debt to GDP ratio is included in the model to capture its impact on economic growth. Public debt sabotages the process of capital formation and encourages capital flight, increases the interest rate, crowd out private investment, increases budget deficits, and creates inflation in the economy, which indirectly affects the growth rate of GDP capita (Teles \& Mussolini, 2014 and Zouhaier \& Fatma, 2014). Savvides (1992) argued that increasing public debt discouraged incentives to invest because the investors feel that the profit so earned would be taken away by the existing foreign creditors in the form of debt payments and its servicing charges. The payment of debt servicing on the part of the debtor country is like an investment tax. Rising debt servicing explicates the foreign exchange earnings as the significant share of it has been used to pay the debt obligations along with interest upon it. Moreover, high debt servicing increases fiscal deficits discourage public savings which either raise interest rate or discourage investment by decreasing the supply of capital, which ultimately results in hampering economic growth. An increase in debt servicing also raises the budget deficit, which forces the government to increase the taxes or borrow from domestic sources or decrease government expenditures. All leads to discouraging economic growth. The general form of the model can be written as:

\section{The Econometric Model}

$$
\begin{gathered}
E G_{i t}=\alpha_{0}++\alpha_{1} \text { Initial GDP }+\alpha_{2} \text { INVESTMENT }_{i t}+\alpha_{3} \text { SCHOOLING }_{i t}+\alpha_{4} \text { FDI }_{i t}+\alpha_{5} \text { OPENESS }_{i t}+\alpha_{6} \text { FD }_{i t} \\
+\alpha_{7} \text { PUBLIC DEBT } \\
\text { it }
\end{gathered}
$$

Where

$$
\alpha_{0}=\text { Intercept }
$$

$i=$ Cross section dimensions.

$t=$ Time-series dimensions.

$\mathbf{E G}_{\mathbf{i t}}=$ Economic growth .

Initial $\mathbf{G D P}_{\text {it }}=$ Initial level of income.

$\mathbf{I N V}_{\text {it }}=$ Investment

SCHOOLING $_{\text {it }}=$ Secondary school enrollment rate

$\mathbf{F D I}_{\mathbf{i t}}=$ Foreign direct investment

OPNNESS $_{\text {it }}=$ Trade openness

$\mathbf{F D}_{\mathbf{i t}}=$ Financial Development

PUBLIC DEBT $_{\text {it }}=$ Public debt (External + Domestic $)$

EMPIRICAL RESULTS AND ANALYSIS

\section{Hausman Test Results}

Hausman test results are presented in table 2, reject the null hypothesis that random effect is appropriate. On the basis, the Hausman test results fixed effect model is used for the estimation of the model.

Table 2: Hausman Test Results- Null Hypotheses is Random Effect Model is Appropriate

\begin{tabular}{lll}
\hline Chi-Sq. Statistic & Chi-Sq. d.f. & Prob. \\
\hline 22.181763 & 7 & $0.0024 * * *$ \\
\hline
\end{tabular}

*** Null Hypothesis rejected at $1 \%$.

\section{Fixed Effect Model (Fem) Results}

The results presented in Table 3 reveal that the coefficient of the initial level of income is negative and significant, which shows the convergence among countries. The value of the coefficient is 1.13 , which indicates the speed of convergence. Investment, which captures the accelerator principle, stimulates economic growth. One percent increase in investment accelerates economic growth by 0.28 percent. The rise in investment brings multiple changes in national income through the accelerator principle. The investment enhances the level of production, generates employment opportunities, which in turn positively stimulates economic growth. It also confirms Solow (1988) contention that when capital grows more compared to labour results in a higher growth rate because of the employment of more capital along with labour.

Table 3: Fixed Effect Model- Dependent Variable: Economic Growth (EG)

\begin{tabular}{lllll}
\hline Variable & Coefficient & Std. Error & t-Statistic & Prob. \\
\hline Initial GDP & -1.130340 & 0.252526 & $-4.476131 * * *$ & 0.0000 \\
\hline INVESTMENT & 0.288958 & 0.129847 & $-2.225368 * *$ & 0.0274 \\
\hline SCHOOLING & 0.005463 & 0.002005 & $2.724113 * * *$ & 0.0071 \\
\hline
\end{tabular}




\begin{tabular}{lllll}
\hline FDI & 2.004768 & 1.582620 & 1.266740 & 0.2070 \\
\hline OPENESS & 0.000541 & 0.000202 & $2.681734 * * *$ & 0.0080 \\
\hline FD & 1.283432 & 0.194903 & $6.584971 * * *$ & 0.0000 \\
\hline PUBLIC DEBT & -0.527927 & 0.066681 & $-2.791718 * *$ & 0.0239 \\
\hline C & 4.353284 & 0.632963 & $6.877631 * * *$ & 0.0000 \\
\hline Number of Observations $=184$ & & & \\
\hline
\end{tabular}

$* * *$ Significant at $1 \%, * *$ At $5 \%$

Moreover, investment brings multiple increases in national income by influencing the evil effect of different negative factors of the economy, i.e., poverty, inflation, income inequality, unemployment, etc. It also stimulates economic growth by encouraging private investment, improving infrastructure, and increasing savings (Uddin and Aziz, 2014). The positive relationship between investment and economic growth is supported by Munnell (1992), De Long \& Summers (1991), Gyimah-Brempong \& Traynor (1999), and Nazmi \& Ramirez (1997). Schooling also has a positive and significant relationship with economic growth. One percent increase in the school enrollment rate increases economic growth by 0.0054 percent. Human capital influences economic growth in various ways. It stimulates economic growth by enhancing the knowledge and skill of the existing population. The improvement in knowledge and skill stimulates economic growth by enhancing the productive capacity of the economy. The positive relationship between school enrollment and economic growth is supported by many studies such as Barro (2001); Yusoff (2011); Barro and Lee (1994); Peter Wobst (2005); Afzal et al. (2008) and McClelland (1966). Foreign direct investment also positively stimulates economic growth, but the relationship is statistically insignificant. Trade openness has stimulated economic growth positively by enhancing the availability of public goods and services, bringing efficiency in resource allocation, and increase total factor productivity (TFP) through technology transfer and knowledge sharing (Barro and Sala-iMartin, 1997). The results obtained are supported by Huang \& Chang (2014); Soukhakian (2007); Klasra (2011); Karras (2003), and Gries et al. (2011). Financial development (FD) has a positive relationship with economic growth. Financial development enhances the pace of economic growth in the country (Shahbaz et al., 2008). One percent rise in FD causes economic growth to increase by 1.28 percent. Financial development increases the returns from the capital by enhancing the efficiency of investment. It minimizes the cost of borrowings, which stimulates investment. It also increases the savings in the economy, which accelerates the pace of economic growth in the country (Pagano, 1993). Public debt has a significant negative association with economic growth. One percent increase in public debt leads to a decrease in growth by 0.25 percent. It also indicates that public debt is a significant predictor of economic growth. As public debt increases, all the increased capital and output go to pay debt along with its servicing charges having an adverse effect on growth. When public debt increases, a major share of domestic capital use to finance debt obligations squeezing the funds available for investment and development purposes, which in turn discourages growth. It confirms the existence of the debt overhang problem in South Asian countries. The debt overhang hypothesis postulates that when the debt level is expected to increase the country's repayment capacity, a significant share of domestic output goes to pay the debt and its servicing charges. This will, in turn, discourage investment as well as economic growth. A high public debt to GDP ratio depresses the circular flow of income due to the higher payment of debt obligations, which discourages the flow of investment and asserts an adverse effect on growth. Moreover, the persistent borrowings on the part of the government result in increasing the rate of interest, which discourages private sector investment. The diminution of investment depresses the growth rate in the country in the future. Further, an increase in borrowing on the part of the government compels the government to adopt discretionary tax measures, which sabotage the saving potential of the economy, increase the interest rate, decrease investment, and ultimately economic growth as well (Elmendorf \& Mankiw, 1999). The results coincide with the empirical findings of Ajayi \& Oke (2012); Ayadi \& Ayadi (2008); Mohamad (2005), and Clements et al. (2003).

\section{Panel Unit Root Test Results}

To check the stationarity of data, verity of panel unit root tests has been applied, e.g. Levin, Lin \& Chu (2002) Unit Root Test, I'm, Pesaran and Shin Unit Root Test (Im, Pesaran \& Shin, 2003), ADF Fisher Unit Root Test and Phillips - Perron Fisher (Phillips and perron, 1988) Panel Unit Root Test (Solow, 1988). A series is stationary if it has zero mean and constant variance. This study uses all methods mentioned above. From Table 4, we conclude that Economic growth, Initial GDP Schooling, FDI, and FD are stationary at the order I(0), and other variables are at the order I(1).

Table 4: Panel Unit Root Test Results

\begin{tabular}{|c|c|c|c|c|c|c|c|c|}
\hline \multirow{3}{*}{ Variables } & \multicolumn{4}{|c|}{$\begin{array}{l}\text { ADF - Fisher Chi-square } \\
\text { \& } \\
\text { PP - Fisher Chi-square } \\
\end{array}$} & \multicolumn{4}{|c|}{$\begin{array}{l}\text { Levin, Lin \& Chu Unit Root Test } \\
\text { \& } \\
\text { I'm, Pesaran \& Shin Unit Root Test }\end{array}$} \\
\hline & $\mathbf{I}(\mathbf{0})$ & & I(1) & & $\mathbf{I}(\mathbf{0})$ & & $\mathbf{I}(\mathbf{1})$ & \\
\hline & Intercept & $\begin{array}{l}\text { Intercept } \\
\& \text { Trend }\end{array}$ & Intercept & $\begin{array}{l}\text { Intercept } \& \\
\text { Trend }\end{array}$ & \& Intercept & $\begin{array}{l}\text { Intercept } \\
\text { Trend }\end{array}$ & ${ }^{\&}$ Intercept & $\begin{array}{l}\text { Intercept \& } \\
\text { Trend }\end{array}$ \\
\hline EG & $\begin{array}{l}15.3408 \\
(0.3553)\end{array}$ & $\begin{array}{l}34.1173^{*} \\
(0.0020)\end{array}$ & $\begin{array}{l}101.951 * * \\
(0.0000)\end{array}$ & $\begin{array}{l}80.6862 * * \\
(0.0000)\end{array}$ & $\begin{array}{l}-0.42124 \\
(0.3368)\end{array}$ & $\begin{array}{l}-0.61898 \\
(0.2680)\end{array}$ & $\begin{array}{l}-9.24543 * * \\
(0.0000)^{* *}\end{array}$ & $\begin{array}{l}-7.21780 * * \\
(0.0000)\end{array}$ \\
\hline
\end{tabular}


https://doi.org/10.18510/hssr.2021.9218

\begin{tabular}{|c|c|c|c|c|c|c|c|c|}
\hline & $\begin{array}{l}45.4848^{*} \\
(0.0000)\end{array}$ & $\begin{array}{l}89.7759 * \\
(0.0000)\end{array}$ & $\begin{array}{l}285.529 * * \\
(0.0000)\end{array}$ & $\begin{array}{l}1280.84 * * \\
(0.0000)\end{array}$ & $\begin{array}{l}-0.57002 \\
(0.2843)\end{array}$ & $\begin{array}{l}.2 .24759^{*} \\
(0.0123)\end{array}$ & $\begin{array}{l}-9.99173 \\
(0.0000)\end{array}$ & $\begin{array}{l}-5.55664 * * \\
(0.0000)\end{array}$ \\
\hline \multirow{4}{*}{ Initial GDP } & 2.25745 & $28.1475^{*}$ & $64.7321 * *$ & 98.8194** & 3.97954 & $-0.89090^{*}$ & $-10.9359 * *$ & $-10.0583 * *$ \\
\hline & $(0.9998)$ & $(0.0136)$ & $(0.0000)$ & $(0.0000)$ & (1.000) & $(0.1865)$ & $(0.0000)$ & $(0.0000)$ \\
\hline & 3.27814 & 25.7654 & $135.134 * *$ & $375.271 * *$ & 4.97456 & -0.83238 & $-9.13817 * *$ & $-9.02429 * *$ \\
\hline & $(0.9985)$ & $(0.0277)$ & $(0.0000)$ & $(0.0000)$ & $(1.0000)$ & $(0.2026)$ & $(0.0000)$ & $(0.0000)$ \\
\hline \multirow{4}{*}{ INVESTMENT } & 14.3569 & 10.7768 & $58.0380 * *$ & $41.8792 * *$ & -0.93251 & 0.19471 & $-3.36381 * *$ & $-1.82436 * *$ \\
\hline & $(0.4235)$ & $(0.7035)$ & $(0.0000)$ & $(0.0001)$ & $(0.1755)$ & $(0.5772)$ & $(0.0004)$ & $(0.0340)$ \\
\hline & 11.0762 & 6.07604 & $98.0147 * *$ & $80.9612 * *$ & 0.10167 & -0.84977 & $-5.63140 * *$ & $-4.15617 * *$ \\
\hline & $(0.6800)$ & $(0.9645)$ & $(0.0000)$ & $(0.0000)$ & $(0.5406)$ & $(0.1977)$ & $(0.0000)$ & $(0.0000)$ \\
\hline \multirow{4}{*}{ SCHOOLING } & 8.48107 & 18.5705 & $46.8601 * *$ & $35.9731 * *$ & -0.61701 & -0.19714 & $-2.41953 * *$ & $-1.63831 * *$ \\
\hline & $(0.8628)$ & $(0.1820)$ & $(0.0000)$ & $(0.0011)$ & $(0.2686)$ & $(0.4219)$ & $(0.0078)$ & $(0.0507)$ \\
\hline & 7.17715 & $43.3847^{*}$ & $79.6024 * *$ & $311.025^{* *}$ & 2.11146 & 0.34865 & $-4.13785^{* *}$ & $-1.16291 * *$ \\
\hline & $(0.9277)$ & $(0.0001)$ & $(0.00000$ & $(0.0000)$ & $(0.9826)$ & $(0.6363)$ & $(0.0000)$ & $(0.1224)$ \\
\hline \multirow{4}{*}{ FDI } & $39.9213^{*}$ & $33.9051 *$ & $106.797 * *$ & $83.0056^{* *}$ & $-2.12924 *$ & $-1.43917^{*}$ & $-6.86023 * *$ & $-5.68908 * *$ \\
\hline & $(0.0003)$ & $(0.0021)$ & $(0.0000)$ & $(0.0000)$ & $(0.0166)$ & $(0.0751)$ & $(0.0000)$ & $(0.0000)$ \\
\hline & $46.1231 *$ & 47.8958 & $177.022 * *$ & $550.030 * *$ & $-3.12094 *$ & $-.53434 *$ & $-9.83286 * *$ & $-5.24242 * *$ \\
\hline & $(0.0000)$ & $(0.0000)$ & $(0.0000)$ & $(0.0000)$ & $(0.0009)$ & $(0.0002)$ & $(0.0000)$ & $(0.0000)$ \\
\hline \multirow{4}{*}{ OPENESS } & 12.5340 & 17.6877 & $73.9535^{* *}$ & $55.9845^{* *}$ & 0.68512 & -0.49804 & $-7.92743 * *$ & $-7.00138^{* * *}$ \\
\hline & $(0.5635)$ & $(0.2214)$ & $(0.0000)$ & $(0.0000)$ & $(0.7534)$ & $(0.3092)$ & $(0.0000)$ & $(0.0000)$ \\
\hline & 12.4420 & 10.1667 & $109.979 * *$ & $98.2954 * *$ & 0.7559 & -0.07977 & $-7.01743 * *$ & $-4.80455^{* *}$ \\
\hline & $(0.5709)$ & $(0.7499)$ & $(0.0000)$ & $(0.0000)$ & $(0.7751)$ & $(0.4642)$ & $(0.0000)$ & $(0.0000)$ \\
\hline \multirow{4}{*}{ PUBLIC DEBT } & 39.9213* & $33.9051^{*}$ & $106.797 * *$ & $83.0056^{* *}$ & -2.12924 & $-1.43917^{*}$ & $-6.86023 * *$ & $-5.68908 * *$ \\
\hline & $(0.0003)$ & $(0.0021)$ & $(0.0000)$ & $(0.0000)$ & $(0.0166)$ & $(0.0751)$ & $(0.0000)$ & $(0.0000)$ \\
\hline & $46.1231 *$ & $47.8958^{*}$ & $177.022 * *$ & $550.030 * *$ & $-3.12094 *$ & $-3.53434 *$ & $-9.83286^{* *}$ & $-8.18007 * *$ \\
\hline & $(0.0000)$ & $(0.0000)$ & $(0.0000)$ & $(0.0000)$ & $(0.0009)$ & $(0.0002)$ & $(0.0000)$ & $(0.0000)$ \\
\hline \multirow{4}{*}{ PUBLIC DEBT } & 7.66782 & 8.68242 & $52.3236^{* *}$ & $33.0418 * *$ & 0.56591 & 1.13205 & $-4.03087 * *$ & $-3.25696 * *$ \\
\hline & $(0.9059)$ & $(0.8508)$ & $(0.0000)$ & $(0.0028)$ & $(0.7143)$ & $(0.8712)$ & $(0.0000)$ & (0.0006) \\
\hline & 9.48437 & 15.2257 & $120.378 * *$ & $93.1499 * *$ & 1.11135 & 0.53655 & $-5.11394 * *$ & $-2.04609 * *$ \\
\hline & $(0.7988)$ & $(0.36290$ & $(0.0000)$ & $(0.0000)$ & $(0.8668)$ & $(0.7042)$ & $(0.0000)$ & $(0.0204)$ \\
\hline
\end{tabular}

Values in Parentheses are p-values. * Stationary at a level. ** At first difference.

So, we can use the Panel ARLD approach to examine the long-run relationship among the variables.

\section{Panel ARDL/ PMG Results}

The Panel, ARDL/ PMG results, presented in table 5, indicate that the coefficient of initial income is negative and significant, which indicates the convergence among countries in the long-run.

Table 5: Panel ARDL Results- Dependent Variable Economic Growth (EG)

\begin{tabular}{lllll}
\hline Variable & Coefficient & Std. Error & t-Statistic & Prob. \\
\hline Long Run Equation & & & & \\
\hline Initial GDP & -1.247754 & 0.237128 & $-5.261938^{* * *}$ & 0.0000 \\
\hline INVESTMENT & 0.603238 & 0.173592 & $-3.475032 * * *$ & 0.0007 \\
\hline SCHOOLING & 0.011834 & 0.002171 & $5.452164 * * *$ & 0.0000 \\
\hline FDI & 3.845502 & 2.255444 & $1.704987 *$ & 0.0909 \\
\hline OPENESS & 0.000358 & 0.000250 & 1.433570 & 0.1544 \\
\hline FD & 1.232444 & 0.191779 & $6.426389 * * *$ & 0.0000 \\
\hline PUBLIC DEBT & -0.308525 & 0.149053 & $-2.069900^{* *}$ & 0.0407 \\
\hline Short Run Equation & & & & \\
\hline COINTEQ01 & $\mathbf{- 0 . 9 0 5 0 2 0}$ & $\mathbf{0 . 1 6 6 9 5 2}$ & $\mathbf{- 5 . 4 2 0 8 4 9 * * *}$ & $\mathbf{0 . 0 0 0 0}$ \\
\hline D(Initial GDP) & 0.275517 & 1.036819 & 0.265733 & 0.7909 \\
\hline D(INVESTMENT) & 1.906314 & 1.337556 & 1.425222 & 0.1568 \\
\hline D(SCHOOLING) & -0.000779 & 0.016147 & -0.048237 & 0.9616 \\
\hline D(FDI) & 2.888074 & 6.540420 & 0.441573 & 0.6596 \\
\hline D(OPENESS) & 0.355692 & 0.444104 & 0.800920 & 0.4248 \\
\hline D(FD) & -1.939049 & 0.725457 & $-2.672866 * * *$ & 0.0086 \\
\hline D(PUBLIC DEBT) & -0.527927 & 0.066681 & $-2.791718 * *$ & 0.0239 \\
\hline C & 3.999808 & 0.673525 & 5.938616 & 0.0000 \\
\hline Number of Observations $=184$ & & & \\
\hline
\end{tabular}


$* * *$ Significant at $1 \%$. ** at $5 \%$.* at $10 \%$

Investment has a positive association with economic growth in the long run (LR). One percent increase in investment brings a 0.60 percent increase in economic growth. Schooling enhances economic growth in LR. Foreign direct investment (FDI) stimulates economic growth. One percent increase in foreign direct investment leads to an increase in economic growth by 3.84 percent. FDI increases the production of the economy by enhancing labour productivity by introducing new technology embedded in the capital. It also enhances the pace of capital formation, enhances industrial productivity, creates employment opportunities, and increases government tax revenues. The positive relation between FDI and economic growth is supported by Ghatak \& Halicioglu (2007), Cambazoglu \& Karaalp (2014), Seyoum \& Lin (2015), Zhang (2001), Lyroudi et al. (2004), and Sharma \& Abekah (2008). Trade Openness stimulates growth. Financial development positively influences economic growth. Public debt has a negative and significant relationship with economic growth. One percent increase in public debt brings a 0.30 percent decline in economic growth. The shortrun results indicate that the error correction term (ECT) is negative and significant at $1 \%$ level of significance, which explains the speed of convergence of the model towards the equilibrium. The PDGDP has a negative and but insignificant relation with economic growth in the SR.

\section{CONCLUSION}

The prime objective of the study is to examine the public debt vs growth nexus in South Asian countries. Developing countries of South Asia are continuously facing problems in managing and servicing their huge stocks of public debt. Their economic performance continues to decline due to the significant outflow of resources to meet their debt obligations. From the literature, various channels through which public debt affects growth have been identified: public debt to GDP ratio, investment as a share of GDP, human capital, financial development, and FDI. Besides these variables, the impact of financial liberalization, captured through trade openness indicator on economic growth has also been analyzed. For the sake of analysis, different econometrics techniques like Fixed Effect Model, Hausman Test, and Panel ARDL have been used to examine the long-run relationship among the variables. The results of the study reveal that public debt has a negative impact on economic growth both in the long run and short run. Further, both external debt and domestic debt are harmful and deleterious effects on economic growth in these countries in the short-run as well as in the long run. Growing public debt compels the country to raise taxes, which puts a constraint on household consumption by squeezing their disposable incomes. Public debt decreases the returns from capital due to higher taxes, discourages incentive to invest, appreciates exchange rate, increases trade deficits and decrease net exports, and has a negative effect on growth. Rising public debt raises the government bill in terms of debt repayments and its services charges, which tempts the government to adopt inflationary measures. Public debt increases public spending due to the accessibility of the government to loans, either internal or external. The practice of increasing public expenditures through borrowed funds has different implications on economic growth, depending on how these funds are utilized. It may be useful in the short run and have a favourable impact on economic growth, but its long-run consequences are different. In contrast, these borrowed funds are spent on development activities such as the construction of infrastructure, energy production, and the importation of necessary machinery and raw material needed for industrialization. They would have the effect of enhancing the productive capacity of the economy. In this case, public spending increase through borrowed funds would have a positive effect on economic growth. But, if these borrowings are spent on unproductive uses, then such public spending would result in increasing the debt burden and harm economic growth. The investors, both domestic and foreign, expect high tax returns on the profits on the part of the government due to growing public debt. The net exports decrease, and the current account deficit is further aggravated having a negative impact on growth. Growing public debt increases the payment of the government in terms of debt and its servicing charges. In this situation, to deal with public debt, deficit financing has to be restored. Deficit financing increases the supply of money and aggregate demand in the country. All this leads to an increase in inflation in the economy. Thus, we conclude the whole discussion that public debt, whichever form, may be harmful to the economy. The government would be very much careful regarding public debt and its uses to avoid its negative repercussions on the economy.

\section{POLICY RECOMMENDATIONS}

Several policy implications emerge from the study. The simultaneous attainment of a sustainable level of economic growth and public debt seems to be difficult at the moment. It could remain elusive if some serious measures have not been taken. There is a need to utilize the borrowed fund effectively and productively. For this purpose, the government should strengthen its policies that could ensure the better and efficient management of public debt for promoting economic growth in the country. The government should make fiscal adjustments through cuts in expenditures, especially in non-development expenditures in order to minimize budget deficits. There is a need to reduce the cost of administrative expenditures. For this purpose, simplicity will be brought up. Defense expenditures will be decreased by making negotiations with arch-rivals regarding different controversial issues. Public spending will be made, keeping in view the development requirements of the economy. The expenditures aim to achieve political gains would be checked by implementing a fair accountability system. Efforts would be made to diversify the exports to increase foreign exchange earnings. The reliance on imports would be decreased. There is a need to win the confidence of both domestic and foreign investors. For this purpose, the government should provide them with a favourable macroeconomic environment needed for investment. The most challenging factor for the government is to ensure the efficiency in the 
delivery of services and enhance the productivity of public investment in the economy. It is, therefore pertinent that an effective and viable monitoring system be put in place to ensure proper and systematic utilization of the borrowed funds for development purposes. For this purpose, good governance having a strong political will that could undertake and implement political and economic reforms required to minimize the reliance on public debt.

\section{LIMITATION AND STUDY FORWARD}

Politicians need to know how sustainable the debt is in order to limit government debt. The most important indicators are the deficit ratio and the government debt/GDP ratio which both contain GDP. The primary balance between revenues and expenditure of the existing budget, excluding interest payments on expenditure and asset sales on the income side, is also an important addition to this. The debt will decrease if the primary surplus exceeds payments of interest. The opposite applies if it is lower or there is a primary deficit. In order to limit government debt, politicians must know how sustainable a debt is. The deficit ratio and the debt/GDP ratio of governments, which both contain GDP, are the main indicators. An important addition to this is also the primary balance between incomes and expenses of the existing budget, excluding expenditure interest payments and income asset sales. If the primary surplus surpasses interest payments, debt will decrease. The contrary applies if the deficit is lower or primary.

\section{ACKNOWLEDGEMENT}

I would like to take this opportunity to say warm thanks to all my co-authors, and colleagues who have been so supportive along the way of doing my research. I also would like to express my wholehearted thanks to my family for their support they provided me throughout my entire life and particularly through the process of pursuing the research paper. Because of their unconditional love and prayers, I have the chance to complete this paper. Last but not least deep thanks to all people who took part in making this thesis real.

\section{AUTHORS CONTRIBUTION}

Gulam Sarwar and Shahzad Mushtaq conceived of the presented idea. Israr Hussain developed the theory and performed the computations. Bashir Ahmad Khan verified the analytical methods. Bashir Ahmad Khan encouraged Israr Hussain Muhammad Reehan Hameed to investigate panel data analysis and supervised the findings of this work. All authors discussed the results and contributed to the final manuscript.

\section{REFERENCES}

1. Adebusola, A. A., Sheu, S. A., \& Elijah, O. A. (2007). The Effects of External Debt Management on Sustainable Economic Growth and Development: Lessons from Nigeria (MPRA Paper No. 2147). University Library of Munich, Germany.

2. Afzal, M., Rehman, H., \& Rehman, J. (2008). Causal Nexus between Economic Growth, Export and External Debt Servicing: The case of Pakistan. Retrieved December 14, 2009. https://www.researchgate.net/p ublication/316738212_Causal_Nexus between_Economic_Growth_Export_and External_Debt_Servicing The Case of Pakistan

3. Agenor, P. R. \& Montiel, P. (1996). Development macroeconomics. Princeton. New Jersey: Princeton University Press.

4. Ajayi, L. B., \& Oke, M. O. (2012). Effect of External Debt on Economic Growth and Development of Nigeria. International Journal of Business and Social Science, 3(12), 297-304.

5. Amassoma, D. (2011). External Debt, Internal Debt and Economic Growth Bound in Nigeria Using A Causality Approach. Current Research Journal of Social Sciences, 3(4), 320-325

6. Anwar, Sabahat (1995) Foreign Debt of South Asia and Its Economic Implications. M. Phil, Thesis. Department of Economic, Quaid-i-Azam University, Islamabad.

7. Ayadi, F. S., \& Ayadi, F. O. (2008). The Impact of External Debt on Economic Growth: A Comparative Study of Nigeria and South Africa. Journal of Sustainable Development in Africa, 10(3), 234-264.

8. Azman-Saini, W. N. W., Law, S. H., \& Ahmad, A. H. (2010). FDI and Economic Growth: New Evidence on the Role of Financial Markets. Economics Letters, 107(2), 211-213. https://doi.org/10.1016/j.econlet.201 $\underline{0.01 .027}$

9. Bakar, A., \& Hassan, S. (2008). Empirical Evaluation on External Debt of Malaysia. International Business \& Economics Research Journal, 7(2), 95-108. https://doi.org/10.19030/iber.v7i2.3226

10. Barro, R. J. (1991). Economic Growth in A Cross Section Of Countries. The quarterly journal of economics, 106(2), 407-443. https://doi.org/10.2307/2937943

11. Barro, R. J. (2001). Education and economic growth. The Contribution of Human and Social Capital to Sustained Economic Growth and Well-being, 14-41.

12. Barro, R. J., \& Lee, J. W. (1994). Sources of Economic growth. In Carnegie-Rochester Conference Series on Public Policy, 40(1), 1-46. https://doi.org/10.1016/0167-2231(94)90002-7

13. Barro, R., \& Sala-i-Martin, X. (1997). Technology Diffusion, Convergence and Growth. Journal of Economic Growth, 2(1), 1-25. https://doi.org/10.1023/A:1009746629269 
14. Benhabib, J., \& Spiegel, M. M. (1994). The Role of Human Capital in Economic Development Evidence from Aggregate Cross-Country Data. Journal of Monetary Economics, 34(2), 143-173. https://doi.org/10.1016/03043932(94)90047-7

15. Berben, R. P., \& Brosens, T. (2007). The Impact of Government Debt on Private Consumption in OECD Countries. Economics Letters, 94(2), 220-225. https://doi.org/10.1016/j.econlet.2006.06.033

16. Butts, H. C. (2009). Short Term External Debt and Economic Growth Granger Causality: Evidence from Latin America and the Caribbean. The Review of Black political economy,36(2), 93-111. https://doi.org/10.1007/s12114-009-9041-7

17. Cambazoglu, B., \& Karaalp, H. S. (2014). Does Foreign Direct Investment Effect Economic Growth? The case of Turkey. Economics, 41(6), 434-449. https://doi.org/10.1108/IJSE-02-2012-0173

18. Caselli, F., Esquivel, G., \& Lefort, F. (1996). Reopening the Convergence Debate: a New Look at CrossCountry Growth Empirics. Journal of Economic Growth, 1(3), 363-389. https://doi.org/10.1007/BF00141044

19. Chiu, Y. B., \& Lee, C. C. (2017). On the Impact of Public debt on Economic Growth: Does Country Risk Matter? Contemporary Economic Policy, 35(4), 751-766. https://doi.org/10.1111/coep.12228

20. Clements, B., Bhattacharya, R. and Nguyen, T.Q. (2003). External Debt, Public Investment, and Growth in Low-Income Countries. IMF Working Paper No. 03/249, IMF, Washington, DC. https://doi.org/10.5089/9781451875904.001

21. De Long, J. B., \& Summers, L. H. (1991). Equipment Investment and Economic Growth. The Quarterly Journal of Economics, 106(2), 445-502. https://doi.org/10.2307/2937944

22. Elmendorf, D. W., \& Mankiw, N. G. (1999). Government Debt. Handbook of macroeconomics, 1, 1615-1669. https://doi.org/10.1016/S1574-0048(99)10038-7

23. Fincke, B., \& Greiner, A. (2015). Public Debt and Economic Growth in Emerging Market Economies. South African Journal of Economics, 83(3), 357-370. https://doi.org/10.1111/saje.12079

24. Ghatak, A., \& Halicioglu, F. (2007). Foreign Direct Investment and Economic Growth: Some Evidence from Across the World. Global Business and Economics Review, 9(4), 381-394. https://doi.org/10.1504/GBE .2007 .015101

25. Ghourchian, S., \& Yilmazkuday, H. (2020). Government Consumption, Government Debt and Economic Growth. Review of Development Economics, 24(2), 589-605. https://doi.org/10.1111/rode.12661

26. Gong, L. \& Zou, Heng-fu (2000). Foreign Aid Reduces Domestic Capital Accumulation and Increases Foreign Borrowing: A Theoretical Analysis. Annals of Economics and Finance, 1(1), 147-163.

27. Gries, T., Kraft, M., \& Meierrieks, D. (2011). Financial Deepening, Trade Openness and Economic Growth in Latin America and the Caribbean. Applied Economics, 43(30), 4729-4739. https://doi.org/10.1080/000 36846.2010.498352

28. Gurbuz, Y., Jobert, T., \& Tuncer, R. (2007). Public Debt in Turkey: Evaluation and Perspectives. Applied Economics, 39(3), 343-359. https://doi.org/10.1080/00036840500438889

29. Gyimah-Brempong, K., \& Traynor, T. L. (1999). Political Instability, Investment and Economic Growth in Sub-Saharan Africa. Journal of African Economies, 8(1), 52-86. https://doi.org/10.1093/jae/8.1.52

30. Hameed, M.R., \& Quddus, M. A. (2020). Impact of High and Growing Public Debt on Economic Growth in SAARC Countries: An Econometric Analysis. Journal of Political Studies, 27(1), 125-142.

31. Harmon, E.Y. (2012). The Impact of Public Debt on Inflation, GDP Growth and Interest Rates in Kenya (Doctoral dissertation). Unpublished. published or unpublished

32. Herzer, D. (2008). The Long-Run Relationship Between Outward FDI and Domestic Output: Evidence from Panel Data. Economics Letters, 100(1), 146-149. https://doi.org/10.1016/j.econlet.2007.12.004

33. Huang, L. C., \& Chang, S. H. (2014). Revisit the Nexus of Trade Openness and GDP growth: Does the Financial System Matter? The Journal of International Trade \& Economic Development, 23(7), 1038-1058. https://doi.org/10.1080/09638199.2013.830638

34. Im, K. S., Pesaran, M. H., \& Shin, Y. (2003). Testing for Unit Roots in Heterogeneous Panels. Journal of Econometrics, 115(1), 53-74. https://doi.org/10.1016/S0304-4076(03)00092-7

35. Intartaglia, M., Antoniades, A., \& Bhattacharyya, S. (2018). Unbundled Debt and Economic Growth in Developed and Developing Economies: An Empirical Analysis. The World Economy, 41(12), 3345-3358. https://doi.org/10.1111/twec.12626

36. Karras, G. (2003). Trade Openness and Economic Growth Can We Estimate the Precise Effect?. Applied Econometrics and International Development, 3(1), 7-25.

37. Klasra, M. A. (2011). Foreign Direct Investment, Trade Openness and Economic Growth in Pakistan and Turkey: An Investigation Using Bounds Test. Quality \& Quantity, 45(1), 223-231. https://doi.org/10.1007 /s11135-009-9272-5

38. Krugman, P. (1988). Financing vs Forgiving a Debt Overhang. Journal of Development Economics, 29, 253268. https://doi.org/10.1016/0304-3878(88)90044-2

39. Levin, A., Lin, C. F., \& Chu, C. S. J. (2002). Unit Root Tests in Panel Data: Asymptotic and Finite-Sample Properties. Journal of Econometrics, 108(1), 1-24. https://doi.org/10.1016/S0304-4076(01)00098-7

40. Levine, R. (2005). Finance and Growth: Theory and Evidence. Handbook of Economic Growth, 1, 865-934. https://doi.org/10.1016/S1574-0684(05)01012-9 
41. Lin, S., \& Sosin, K. (2001). Foreign Debt and Economic Growth. Economics of Transition, 9(3), 635-655. https://doi.org/10.1111/1468-0351.00092

42. Lopes da Veiga, J. A., Ferreira-Lopes, A., \& Sequeira, T. N. (2016). Public Debt, Economic Growth and Inflation in African Economies. South African Journal of Economics, 84(2), 294-322. https://doi.org/10.1111/saje.12104

43. Lopez, P. J., \& Nahon, C. (2017). The Growth of Debt and the Debt of Growth: Lessons from the Case of Argentina. Journal of Law and Society, 44(1), 99-122. https://doi.org/10.1111/jols.12016

44. Lyroudi, K., Papanastasiou, J., \& Vamvakidis, A. (2004). Foreign Direct Investment and Economic Growth in Transition Economies. South-Eastern Europe Journal of Economics, 2(1), 97-110.

45. Maghyereh, A. (2003). External Debt and Economic Growth in Jordan: The Threshold Effect. Economia Internazionale/International, Economics 56(3), 337-355. https://doi.org/10.2139/ssrn.317541

46. Mankiw, N. G., Romer, D., \& Weil, D. N. (1992). A Contribution to the Empirics of Economic Growth. The quarterly journal of economics, 107(2), 407-437. https://doi.org/10.2307/2118477

47. Mbate, M. (2013). Domestic Debt, Private Sector Credit and Economic Growth in Sub-S Saharan Africa. African Development Review, 25(4), 434-446. https://doi.org/10.1111/1467-8268.12040

48. McClelland, D. C. (1966). Does Education Accelerate Economic growth? Economic Development and Cultural Change, 14(3), 257-278. https://doi.org/10.1086/450163

49. Mohamed, M. A. A. (2005). The Impact of External Debts on Economic Growth: An Empirical Assessment of Sudan: 1978-2001. Eastern Africa Social Science Research Review,21(2), 53-66. https://doi.org/10.1353/eas.2005.0008

50. Molina, G. G., Ortiz-Juarez, E., \& NETWORK, U. G. P. (2020). Temporary basic income: Protecting poor and vulnerable people in developing countries. United Nations Development Programme.

51. Munnell, A. H. (1992). Policy Watch: Infrastructure Investment and Economic Growth. Journal of Economic Perspectives, 6(4), 189-198. https://doi.org/10.1257/jep.6.4.189

52. Nazmi, N., \& Ramirez, M. D. (1997). Public and Private Investment and Economic growth in Mexico. Contemporary Economic Policy, 15(1), 65-75. https://doi.org/10.1111/j.1465-7287.1997.tb00455.x

53. Pagano, M. (1993). Financial Markets and Growth: An Overview. European Economic Review, 37(2-3), 613622. https://doi.org/10.1016/0014-2921(93)90051-B

54. Pervaiz, Z., \& Chaudhary, A. R. (2015). Social Cohesion and Economic Growth: An Empirical Investigation. Australian Economic Review, 48(4), 369-381. https://doi.org/10.1111/1467-8462.12128

55. Peter Wobst, H. S. A. (2005). The Impact of Increased School Enrollment on Economic Growth in Tanzania. African Development Review, 17(2), 274-301. https://doi.org/10.1111/j.1017-6772.2005.00116.x

56. Phillips, P. C., \& Perron, P. (1988). Testing for a Unit Root in Time Series Regression. Biometrika, 75(2), 335346. https://doi.org/10.1093/biomet/75.2.335

57. Reinhart, C. M., and Rogoff, K. S. (2010). Growth in a Time of Debt (Digest Summary). American Economic Review, 100(2), 573-578. https://doi.org/10.1257/aer.100.2.573

58. Romer, P. M. (1990). Human Capital and Growth. Theory and Evidence. In Carnegie-Rochester Conference Series on Public Policy, 32 (1), 251-286. https://doi.org/10.1016/0167-2231(90)90028-J

59. Saez, L. (2012). The South Asian association for regional cooperation (SAARC): An emerging collaboration architecture. Routledge. https://doi.org/10.4324/9780203808801

60. Savvides, A. (1992). Investment Slowdown in Developing Countries During The 1980s: Debt Overhang or Foreign Capital Inflows? Kyklos, 45(3), 363-378. https://doi.org/10.1111/j.1467-6435.1992.tb02121.x

61. Serieux, J. \& Samy, Y. (2001). The Debt Service Burden and Growth: Evidence from Low-income countries. Paper Presented at the Wider Conference on Debt Relief, 17-18 August, Helsinki: UNU/WIDER.

62. Seyoum, M., Wu, R., \& Lin, J. (2015). Foreign Direct Investment and Economic Growth: The Case of Developing African Economies. Social Indicators Research, 122(1), 45-64. https://doi.org/10.1007/s11205014-0679-6

63. Shahbaz, M., Ahmad, K., \& Chaudhary, A. R. (2008). Economic Growth and its Determinants in Pakistan. The Pakistan Development Review, 47(4), 471-486. https://doi.org/10.30541/v47i4IIpp.471-486

64. Sharma, B., \& Abekah, J. (2008). Foreign Direct Investment and Economic Growth of Africa. Atlantic Economic Journal, 36(1), 117-11. https://doi.org/10.1007/s11293-007-9103-9

65. Shonchoy, A. (2010). What is Happening with the Government Expenditure of Developing Countries-A Panel Data Study (No.2). Verein für Socialpolitik, Research Committee Development Economics.

66. Solow, R. M. (1988). Growth Theory and After. The American Economic Review, 78(3), 307-317.

67. Soukhakian, B. (2007). Financial Development, Trade Openness and Economic Growth in Japan: Evidence from Granger Causality Tests. Journal of Economic \& Management Perspectives, 1(3), 118.

68. Sunde, T. (2017). Foreign Direct Investment, Exports and Economic Growth: ADRL and Causality Analysis for South Africa. Research in International Business and Finance, 100(41), 434-444. https://doi.org/10.1016/j.r ibaf.2017.04.035

69. Swamy, V. (2020). Debt and growth: Decomposing the Cause-and-Effect Relationship. International Journal of Finance \& Economics, 25(2), 141-156. https://doi.org/10.1002/ijfe.1729 
70. Tchereni, B. H. M., Sekhampu, T. J., \& Ndovi, R. F. (2013). The Impact of Foreign Debt on Economic Growth in Malawi. African Development Review, 25(1), 85-90. https://doi.org/10.1111/j.1467-8268.2013.12015.x

71. Teles, V. K., \& Mussolini, C. C. (2014). Public Debt and the Limits of Fiscal Policy to Increase Economic Growth. European Economic Review, (66), 1-15. https://doi.org/10.1016/j.euroecorev.2013.11.003

72. Uddin, M. M., \& Aziz, S. (2014). Effect of Public Investment on Economic Growth in Bangladesh: An Econometric Analysis. Journal of Economics and Sustainable Development, 5(22), 37-50.

73. UNDP. (1997). Report on millennium development goals. New York, NY.

74. Ravallion, M. (1997). Good and bad growth: The Human Development Reports. World Development, 25(5), 631-638. https://doi.org/10.1016/S0305-750X(96)00141-6

75. Ward, H. P., Ricci, L., \& Pattillo, C. (2002). External Debt and Growth. External Debt and Growth, International Monetary Fund, 2(69), 1-47. https://doi.org/10.5089/9781451849073.001

76. Yusoff, M. B. (2011). Zakat Expenditure, School Enrollment, and Economic Growth in Malaysia. International Journal of Business and Social Science, 2(6), 175-181.

77. Zaidi, S. A. (2015). Issues in Pakistan's Economy. Oxford University Press, Pakistan.

78. Zhang, K. H. (2001). Does Foreign Direct Investment Promote Economic Growth? Evidence from East Asia and Latin America. Contemporary economic policy, 19(2), 175-185. https://doi.org/10.1111/j.14657287.2001.tb00059.x

79. Zouhaier, H., \& Fatma, M. (2014). Debt and Economic Growth. International Journal of Economics and Financial Issues, 4(2), 440-448. 